\title{
Karin Sanders
}

\section{White Oblivion: Antarctica and the Suspension of Trauma}

Trauma is often seen as the accumulation of several events incited and experienced generations apart. In Trauma Culture from 2005, E. Ann Kaplan notes, for example, that the shock experience of the twentieth century, with the Holocaust as the crucial event, has prompted a ripple effect of trauma experiences in the personal lives of those born after the fact. The past haunts the present, sometimes as an uncanny repetition, but almost always as a delayed response. At the other end of the temporal spectrum, anticipation of a future trauma in the form, for example, of the aftershocks of a global ecological disaster can have ripple effects in reverse. The all-too-predictable climate catastrophe of the future is already ascertainable in a generation that has not yet fully experienced it. Instead of a delayed response to a past event, we find an advance response to a future event.

\section{White oblivion}

A memoir by English author Jenny Diski (1947-2016), Skating to Antarctica from 2005, offers yet a third possibility: the suspension of the effect of trauma in the present. Diski makes use of trauma circumvention by searching for a space of deliberate forgetfulness. To do so, she employs two central images: the first is whiteness and ice connected to a trip to Antarctica, and the second is the socalled Schrödinger's box and the possibility of a superposition of states. A suspension of knowing!

The memoir starts with this opening line: “I'm not entirely content with the degree of whiteness in my life. My bedroom is white, white walls, icy mirrors, white sheets and pillowcases, white slatted blinds.... / when I wake, I can open my eyes to nothing but whiteness" (Diski 2005: 1). We soon learn that white is not only connected to Diski's preferred color of interior decorating, but also to her childhood experience of practicing in an ice rink, her incidents of institutionalization in psychiatric hospitals, and finally to a longing for the ultimate whiteness that she hopes to find in Antarctica: "I wanted white and ice for as far as the eye could see" (Diski 2005: 5). Whiteness frames a dark and traumatic childhood, as the past is searched for clues to piece together an acutely painful mother-daughter relationship. It becomes a kind of non-image, an image of ultimate

Ә OpenAccess. () 2020 Karin Sanders, published by De Gruyter. (cc))BY-NC-ND This work is licensed under the Creative Commons Attribution-NonCommercial-NoDerivatives 4.0 License. 
(albeit failed) forgetfulness, but also, as the memoir proceeds, a powerful mnemonic. In fact, Diski's obsession with whiteness "seemed to hold out the promise of what I really wanted: a place of safety, a white oblivion” (Diski 2005: 2).

"White oblivion" turns out to be a rather paradoxical image throughout the book, one that is meant as an empty space, un-inscribable, yet one that nevertheless serves as a sponge that draws the forgotten and repressed memories into or onto the book pages. It opens for a particular negative inflection of ekphrastic power, a kind of defiant or reluctant imagery that resists easy or overt visualization. Said differently, the ekphrastic desire to offer some form of clarity by making things visible is troubled by the very restrictions that Diski attaches to her use of imagery. She seeks a whiteout that is, in some sense, also a blackout. Her writing illustrates how images of white suggest not only numbness and absences, but also how this whiteout as blackout makes things sentient and present, not unlike marks of writing on a blank page. Both "whiteouts and blackouts," as Werner Bigell has shown in his essay "Fear and Fascination: AntiLandscapes between Material Resistance and Material Transcendence," can be seen as "limitations imposed by the material world" (Bigell 2014: 9) and for Diski the white sheets in her bedrooms both at home and at the psychiatric hospital are certainly limitations of a material nature. But what she seeks in the journey to Antarctica is perhaps closer to another kind of limitation inherent in what David E. Nye has called anti-landscapes, "[where] human control over the world is limited" (Bigell 2014: 137); Antarctica appeals to her because there is a promise of letting go of control and of searching for answers, a promise of blissful forgetfulness and anesthetizing not-knowing.

To Diski then, white oblivion is a paradoxical space of being, a limbo that is the result of trauma. We learn, for example, about severe psychological and sexual abuse by a mother who emotionally crushed the child until she was saved (as a teenager) by a classmate's mother (none other than the author Doris Lessing, a detail that is omitted from the book). We also learn of a deceased, charismatic, but troubled father, who, like the mother, had violated the daughter.

Much of this information is told by Diski describing her younger self in third person as "Jennifer," a kind of fictional character: "I remember Jennifer with about the same clarity that I remember the young Jane Eyre, Mary from The Secret Garden, Peter Pan and Alice" (Diski 2005: 81). Jennifer "retains only a dim inner illumination" to the reminiscing Diski, and is fuzzier than the fictional characters (Diski 2005: 81). Indeed, "she [Jennifer] is far less substantial than Tinkerbell, who can be brought back into existence through the will of others" (Diski 2005: 81). The author's childhood self, then, is precariously porous and difficult to grasp, not least because Diski is missing witnesses or "corroborating evidence for her existence" (Diski 2005: 81). 
It is a part of Skating to Antartica's mission to provide these missing witnesses, or at least some of them, as Diski cuts between childhood memories, interviews with old neighbors who knew her (as Jennifer) in childhood, the trip to Antarctica, and finally her own daughter's detective work to find out whether the mentally unstable grandmother, Jennifer/Diski's mother, now absent for three decades, is in fact still alive. The answer is found on the last pages of the book.

\section{Wide white horizons}

The white is pursued in the extreme, and to reach the optimal effect, the Arctic to the north is not extreme enough:

The Arctic would have been easier, but I had no desire to head north. I wanted white and ice for as far as the eye could see, and I wanted it in the one place in the world that was uninhabited (never mind the penguins, seals and base camp personnel for the time being). I wanted my white bedroom extended beyond reason. That was Antarctica, and only Antarctica. (Diski 2005: 5)

Antarctica, then, is to Diski the ultimate imaginary, endless and deserted, a place that seems to be the end of the world, a place out of human control, but also one that functions as a foil for the "lost continent of emotional paralysis and disconnection" in her own life, as Maria Flok noted in her review in New York Times (Flok 1998: n.p.). In this sense, the ice works as an extended metaphor for Diski. She comes to realize that "oblivion is a place that has no coordinates in time or space" and that "wilderness is not merely a phenomenon of rugged terrain and hostile elements" but can be "a forbidding world within the mind" (Flok 1998: n.p.).

Diski, of course, is not the first writer or artist to see the possibilities in the whiteness of ice and snow as a foil for endless projections. Most famously, Mary Shelley's Victor Frankenstein, lost on the ice, reflects in ways that must have inspired Diski. At a time of much despair, the icy landscape gave comfort to the troubled scientist:

These sublime and magnificent scenes [caused by glaciers] afforded me the greatest consolation that I was capable of receiving. They elevated me from all littleness of feeling; and although they did not remove my grief, they subdued and tranquilized it. In some degree, also, they diverted my mind from the thoughts over which it had brooded for the last month. (Shelley 1994: 119) 
As Eric G. Wilson suggests in The Spiritual History of Ice, "the glaciers are to Victor oblivion, the absence of human thought. Their icy movements decenter human cares. They calm anxious men to unthinking stones" (Wilson 2003: 131). Diski, too, seeks to decenter her human cares and turn to the absence of reflection and the numbness that the cold landscape promises. Like Victor, she seeks an "excuse to avoid awareness" (Wilson 2003: 132).

It is possible to track an evolution in human encounters with ice from a spiritual experience to psychological and finally traumatic experiences, with the ice rapidly melting into shock points of our present. In antiquity and up until the Romantic age, ice predominately connoted something demonic, hellish, and deadly. The ninth circle at the very center in Dante's fourteenth-century Inferno exemplifies this. Here we find the devil imprisoned in ice with the worst of sinners, condemned and unable to move in their frozen states. Enlightenment's scientific probing of the material world promoted the study of ice crystals in the form of mechanical laws to reveal the extreme delicacy of nature's work, and soon the Romantics discovered in ice a spiritual dimension, and ice started to resonate in works like Mary Shelley's, such as Coleridge's, Emerson's, and Melville's. According to Wilson, ice was seen by many of the Romanticists as a substance not only alive, but in constant tension between transcendence and immanence. Chaotic and calm, centripetal and centrifugal, ice seemed to hold mysterious powers with its own particular vitality.

When Diski makes use of the white ice as a kind of oblivion, this "ultimate otherworld" is already full of images and myths and not just a blank page to be inscribed. For centuries, the Arctic and Antarctica have been seen as beckoning places; the poles became sites for man (rarely woman) to conquer. The sublime chaos of the Arctic and the Antarctic had to be colonized, tamed, named, and checked off as yet another victory for mankind. Nevertheless, the poles remained for many white blank places where "nothing happened" and therefore posed a challenge in their very passivity to the activity of humans, as Robert McGhee has shown in his study of the Arctic as The Last Imaginary Place.

To Diski, however, past expeditions to Antarctica remain more mental than physical, and she quotes from a description by a survivor of the doomed Robert Scott expedition to the South Pole in 1912, Apsley Cherry-Garrard, who, in his account The Worst Journey in the World, recounts Scott's peevish, depressed, and moody temperament, which was not up to the challenges of his quest - a fact that was silenced in the aftermath of the tragedy. Clearly, the heroes of previous Antarctic quests are not exempt from human weakness. Diski's own journey is decidedly non-heroic and can easily be read as an insistence on questioning or even expunging culturally entrenched celebrations of man's courageous capturing of places that continually and constitutionally (the dangerous coldness) 
resist human interference. She does not travel to the vast white continent because of its promise, but because it holds no promise for her - except oblivion.

\section{Passivity, abstraction, and anticipated failure}

Diski's depiction of the vast continent is not one of clichéd sublimity. In fact, by using irony and caustic dryness, she mostly avoids the risk of turning Antarctica and ice and whiteness into complacent and restorative metaphors for mental pain. While trauma can be seen as a facet of the sublime, Diski rejects the opportunity to use the Arctic sublime as an image of pain. Rather, she expects disappointment in advance, an anticipation of failure and disenchantment rehearsed during her childhood practices at her local ice rink where her mother wanted to make an ice princess of her, but where she instead turned into a very different sort of "ice maiden" (her own term) who retrospectively notes that:

An ice rink is as a cruel reminder of reality as any that has been devised. It is a surface artificially constructed to be as friction-free as you can get it. [...Yet] [a]n ice rink is a promise made purely for the pleasure of creating disappointment. (Diski 2005: 8)

The ice rink only allows the skater to go around in circles. But the ice, the whiteness, and the repetition also allow for a meditative concentration and forgetfulness. And it is this forgetfulness - white oblivion - that Diski seeks to use as recuperation in Antarctica:

I wasn't in search of life and death, but of what there is or isn't before and after. Changeless stuff. Empty stuff. Oblivion. (Diski 2005: 49)

What she is looking for is not a sense of meaning or purpose, nor some concrete resolution, but the kind of abstraction that Maurice Blanchot has linked to passivity in his Disaster of Writing. Writing her memoir is seen not so much as an active recuperation of physical and sensual mnemonics, but as an unclear and ambiguous desire to write in ways of white:

My motives were as indistinct as the landscape I was wishing to travel to. There was simply an irrational desire to be at the bottom of the world in a land of ice and snow. I wanted to write white and shades of white... (Diski 2005: 120)

On the cruise ship that brings her to Antarctica, Diski is thrilled to find that her cabin is entirely white - sparse and undecorated, allowing her both literally and symbolically to sail to the end of the world in her white bedroom. Here she reads 
Melville, of course, and cites this well-known passage from "The Whiteness of the Whale" from Moby Dick (1851) with its crucial question about whiteness as negation and absence:

Is it that by its definiteness it shadows forth the heartless voids and intensities of the universe, and thus stabs us from behind with the thought of annihilation when beholding the white depth of the milky way? Or is it, that as in essence whiteness is not so much a colour as the visible absence of colour, and at the same time the concrete of all colours; is it for these reasons that there is such a dumb blankness, full of meaning, in a wide landscape of snows - a colourless, all-colour of atheism from which we shrink? (Diski 2005: 181)

Diski's answer to Melville's question is “yes.” But if white is a blankness full of meaning and a color full of all colors, the ice and whiteness of the Antarctica, Diski suggests, becomes both an "intolerable blankness" and a "blank reality" that necessitates a "toying with the void that finally toys with us" (Diski 2005: 183).

It turns out, however, that to travel into this space of passivity and abstractions takes some cunning planning. In fact, just as the urge to travel to Antarctica in the first place is not only deeply inconvenient - as inconvenient, she says, as a "sexual compulsion" (Diski 2005: 4) - actual access to this desired place turns out to be almost impossible to gain for non-scientists. As a last resort, she must turn to a cruise trip filled with aging tourists who are filling their bucket lists with snapshots of the precarious continent.

The arrival at and entry into Antarctica is described via an image of violence. When the cruise ship, after a long passage, finally sails into the ancient, more than ten-thousand-year-old ice sheets, it is seen as an unjustified destruction, a dreadful disturbance of nature's own design, a kind of fractured and violent ekphrastic moment:

There is something terrible about this, about breaking up the pattern just because we wanted to get beyond it. No real damage was done, but something artful in nature was dislocated. The design was spoiled. (Diski 2005: 215)

The artful patterns, the icy landscape's self-visualizing or self-representation, broken so cruelly by a ship full of photo-clicking and sight-hungry elderly excursionists, is both a poignant image and a sad commentary on the meeting between man and nature. The spoiled design of a heretofore unspoiled nature "pattern" is violent and frightening, a dislocation that folds the narrative of personal trauma together with the narrative of climate change. We do not believe that "no real damage is done" just as we do not believe that Jennifer is not "damaged" by her traumas. Rather, we experience what the American Earth Art pio- 
neer Robert Smithson called "that area of terror between man and land" (Smithson 1996: 238). When the land is fluid, malleable, unstable, and risky, "the world is slowly destroying itself," Smithson predicted; in fact, the "catastrophe comes suddenly, but slowly" (Smithson 1996: 250). It is this potential for suspended cataclysm that Diski mines for possible importance. Yet, although Diski feigns a commitment to non-recovery of past trauma, her utterances are soon seen to be (deliberately) unreliable, contradicted by the narrative itself.

\section{Superposition of states}

The journey to Antarctica is continually cross-cut in the narrative with another journey, a return to the apartment building in London where Diski grew up in a troubled home, gradually stripped of everything: father, furniture, books, until nothing remained but the child's white gloves and an evicted and mentally disturbed mother, whom she loses contact with as a teenager. Throughout the memoir, Diski explicitly pronounces to the reader (and to her inquisitive daughter) that she has no desire to find out what happened to her mother; the grandmother that the daughter has never met. Yet the book is, not surprisingly, crafted precisely around the suspense of what happened. Was she dead? Or was she still alive?

Diski's insists on putting a "lid on" the past, and her refusal to find out about her mother's existence is described by way of the so-called Schrödinger's box:

Imagine a box, inside which is a flask of hydrocyanic acid, some radioactive material, a Geiger counter - and my mother. The apparatus is wired up so that if the radioactive material decays, the Geiger counter will be triggered and will set off a device to shatter the flask and therefore kill my mother. We set the experiment up, shut the lid of the box, and wait until there is a precise fifty-fifty chance that the radioactive decay has occurred. What is the state of my mother before we open the lid to look? (Diski 2005: 22)

The thought experiment points to the so-called superposition of states from quantum theory. It works here as a powerful literary metaphor for suspension of knowledge about the key agent of her trauma. As long as the lid has not been removed and the content has not been observed, the possibility that the mother is alive or dead is equal. As long as the box is unopened, the mother is, in other words, both dead and alive.

Diski prefers this hypothetical model to the psychoanalytical practice that wants to excavate and bring into view the repressed trauma she has endured by her abusive mother. Her desire to travel to Antarctica's whiteness suggests 
that she prefers an extended superposition of states. She wants to avoid knowing (avoidance is a classical trait in trauma). No lids are to be opened in a state of white oblivion by this reluctant traveler. "I wanted to be unavailable and in that place without the pain. I still want it. It is colored white and filled with a singing silence" (Diski 2005: 227). Diski's daughter, on the other hand, sets out to open the lid in her mother's absence, as we learn toward the end of the book.

When the author arrives in Antarctica, she is unsure whether she should even set foot there. It is the not-arriving she sees as freedom. Like the not-opening of the lid, not (yet) knowing the fate of her mother, the reader is not told and will never fully know if the author did, in fact, set foot on Antarctica or if she remained in her white cabin. While Diski explicitly insists on a superposition of states, her memoir implicitly leaves it to the daughter to do the work, not in a psychoanalytical opening of the trauma box, but more palpably by opening the archives and finding, at last, the grandmother's death certificate. This transference of power to her daughter to clear the path to the past takes place while Diski herself is ensconced in her white cabin on the cruise ship amongst white icescapes.

As mentioned, Diski makes a point out of navigating clear of conventional psychoanalytical explanations of trauma; she does not subscribe to Freud's so-called royal road to the unconscious, as he calls it in his Interpretation of Dreams, nor does she believe in what she sees as an all-too-predictable Freudian notion of trauma effects and affects. Her manifest refusal to see personal trauma as something psychoanalytically recoverable, and her voluntary displacement to a place of white oblivion, are not meant to crack open any kind of trauma to be placated, but rather to maintain the sense of numbed nothingness that is also the consequence of the unopened lid on her own personal Schrödinger's box. Not-knowing gives a sensation of nothingness, an almost narcotic pleasure.

Yet, in spite of this refusal to acknowledge trauma, Diski's narrative, I want to suggest, does the work that the author says she wants to avoid: in spite of the intended white-out of the mother, the book gradually lays bare the painful past and, ultimately, offers some kind of resolution. The memoir is quite meticulously structured to allow someone else (the reader, the daughter) to take control over the author's propensity for excesses of white oblivion.

This is perhaps most clearly seen in Diski's explanation for her turn from fiction to nonfiction. She seeks, she writes, another language for the suppression of the painfully remembered. Fiction, as common psychoanalytical wisdom holds, allows us to dip into the subconscious by producing imaginary trials that restore the order of things; that is, fictions can resolve what seems otherwise unresolvable. Yet, traumatized persons, as trauma research (from Freud to Caruth, Fel- 
man, and LaCapra) also implies, cannot control their own mental fictions. Diski discovers that nonfiction (and the use of actual agents like her daughter, or previous Antarctica travelers used as historical proxies) allows her to let go of the authorial control that fiction asks from its writers, frees her from the demands of choice and action, of a kind of witnessing from within the very experience itself - as trauma scholars, such as Caruth (see 1995: 10) would say - and permits her to allow someone else to open the lid on the box, trouble the clichéd echo of the silence of whiteness, and finally let the cat - her mother - out of the box.

\section{Historical contingencies and visual overlay}

There are no deep ecological thoughts to be found in Diski's narrative, but a clear concept of contingency. The way we see and treat nature, she argues, is historically conditional. When the wealthy tourists on the cruise ship hiss at a documentary about whaling followed by "oohs and ahhs of love for nature" as they watch "pictures of whales gloriously breaching, blowing, diving, swimming with their young” (Diski 2005: 131), she sees it as mere hypocrisy and entitlement:

I like a whale as much as the next person. I'm entirely in favour of animals as well as people being let alone if at all possible. I do not like our ravening Homo sapiens way with the world, though of course our Homo sapiens way is only more effective ravening than other species can manage. But we had there a boatful of rich folks booing at their wicked forebears for killing something dramatically large [...]. We no longer need whale bones for our underwear or for anything which plastic makes for better. Take away our electricity and petroleum by-products and we would be in the dark and much inconvenienced (Diski 2005: 131).

Therefore, the self-righteousness of the comfortable and privileged cruisers leaves Diski to see them as "a lot uglier" than the whalers "stripping whale blubber with their flensing knives” (Diski 2005: 132).

Onboard the cruise ship, film viewing, like the whaling documentary mentioned above, serves to entertain the travelers. But the projection of historical footage also serves as a kind of dramatic visual overlay of the present polar experience (the cruise ship) with past ones. Here Diski produces a series of suggestive ekphrastic moments. Scenes from former expeditions, such as Ernest Shackleton's to the Antarctic, implicitly invite the comfortable spectators, snugly cuddled in the safety of a well-stocked luxury vessel, to imagine a far riskier endeavor provided by the filmstrips of the ill-fated expedition in the past.

The historical scene, projected from a video version of a brittle film strip by Frank Hurley of the famed Endurance expedition, makes Diski reflect that the 
film "looked so fragile that we might have been looking at moving, barely moving, pictures of the court of Elizabeth I" (Diski 2005: 132). The footage of the Endurance tragically crushed by the ice captures Diski's imagination: "Hurley's moving pictures only got as far as the moment when the Endurance finally sank and they took off on the ice floe," but Hurley "kept the moving film of the early part of journey as best he could, but even with modern restoration it looked as ancient as papyrus" (Diski 2005: 132-133).

This simile is telling. It serves both to create a sense of a deep past (as ancient as papyrus) and offers a visual image that echoes her own past, as we shall soon see. Although Diski repeatedly voices ambivalent feelings about visual reproduction, sometimes bordering on disdain, she crafts an ekphrastic image that has all the earmarks of a sublime icescape uncannily similar to the one we know from Caspar David Friedrich's fêted painting Das Eismeer from 1823-24:

The ship beset in the ice was covered with rime, grandiose and monumental, like a sculpture - it's a famous picture, but the movie version of the Endurance breaking up, creaking, wailing, sometimes seeming to scream as it buckled at the centre, with the main mast crashing to the deck and the whole thing finally sinking beneath the ice, is heart-stopping. (Diski 2005: 133)

The soundtrack that Diski here adds to the Endurance's demise, the wailing and screaming, obviously does not belong to the original filmstrip, but is either added later in the video representation that she and her fellow travelers watch, or by her own imagination. It adds not only pathos and drama to the scene on the screen, but also anthropomorphizes the ship's pain! Her dramatic audio-ekphrastic description suggests a strong sense of residual and shared trauma with the doomed ship, but also a melancholic pulling of the heartstrings that is deepened when she continues,

[...] the crew desperately trying to find a way through the closing of the ice. While some men hacked at the edges of the pack to make a split in the floe, others hauled on a rope to drag the ship through the narrow way that had been cut. The film was so frail at this point that the line of the men and the rope between them seemed to bleed darkly into each other, blurring the individuals until they appeared to be umbilically attached to their own shadows. (Diski 2005: 134)

The umbilical cord between the doomed men and their shadows offers an almost ghostly connection to the spectators, who the very "next morning [...] would arrive at the place where, just days later, he [Shackleton] were buried" (Diski 2005: 
134). ${ }^{1}$ In fact, there is a constant preoccupation in the narrative with a kind of elasticity of time found in photographic capturing. Footage, as Diski shows, can pull the past closer to the present, as happens here, but can also, as seen with the earlier papyrus comparison, make it seem positively prehistoric.

The melancholic scenes from the fragile filmstrip are implicitly juxtaposed with the sad face of a fellow English female traveler, who seemed chronically depressed and with whom it was difficult to have a conversation: "Her face was set as if in perpetual mourning - the first time you saw her you thought she must have learned something catastrophic, a death in the family, and you wondered whether it would be fitting to go and try to console her" (Diski 2005: 134). This "uncomfortably familiar and frightening" visage is etched in the readers mind when Diski, gazing at the infinite reach of the horizon from the cruise ship's deck, is suddenly jolted back to a superposition of states. Reflecting on her daughter's possible discovery of her mother's death certificate, she feels nothing "[...] and then a shock: if she is dead, then she has been alive all those years intervening years, living breathing, sharing the same air on the same planet. Her death would indicate her previous life, and this was quite a disturbing thought” (Diski 2005: 137).

In a single existing childhood photograph of herself and her mother (bringing obvious associations to Roland Barthes's late theories on photography's affecting possibilities), she finds the same blurring of humans and shadows that she saw in the Shackleton images: "Her shadow and mine blur together into a unified shape, as umbilical as the creaky film of Shackleton's roped-together men trying to pull the Endurance through the ice floe" (Diski 2005: 149). This deliberate ekphrastic overlay of the Endurance's filmstrip with her own motherdaughter photo adds a historical dimension that pulls the past to the present, and vice versa. It creates proximity, but also distance.

Unlike the emotive singularity of the two umbilical images (the fragile filmstrips and the photograph with her mother), the relentless photo shooting by her fellow tourists of anything and everything they observe is presented as a crass disruption of the visual silence that Diski craves. Although she admits that not taking any photos on such an astonishing journey would be "perverse," she nevertheless shudders at the constant "snapping off film like there is no tomorrow" by everyone else. The apparatus is quite simply in the way of vision. You "can't see if you're always composing what is in front of you" (Diski 2005: 145). This explicit suspicion, even hostility, toward photography (she sees it as a form of col-

1 Shackleton did not die in connection with the Endurance calamity in 1915, but of a heart attack on a later expedition in 1922. 
onizing) is ultimately embodied in the "most offensive person on the trip," (Diski 2005: 146) a tactless Scandinavian professional photographer, who rudely elbows and commandeers everyone around while aggressively shooting off his camera. His constant recording leaves no possibilities for white oblivion.

Diski's resistance toward the visual noise of her co-travelers and their overeager and aggressive picture-making echoes her expressed reluctance toward fixed imagery in general. It seems that aggressive picturing is a way of "colonizing” emotion. Consequently, the affects that are attached to her painful and traumatic memories of the past cannot be visualized in a stabile form. It cannot be a crude snapshot, nor a simple ekphrastic representation. There is a slipperiness in the use of images that indicates a hesitation in committing to picturing the past in any manifest way. Instead, the erasure and quietude suggested in "white oblivion" points to a kind of transparency, a ghost-like shadow-play like the umbilical images where the unified shape of the mother and daughter echoes Shackleton's stranded men on the ice floe, holding on to their mothership.

\section{Out of whose womb came the ice?}

It is telling that Diski includes in her narrative the stanza, written on a single page, that Shackleton saved from his bible after sacrificing all excess equipment in order to travel as lightly as possible. On the page, the words of Job read:

Out of whose womb came the ice?

And the hoary frost of Heaven, who hath gendered it?

The waters are hid as with a stone

And the face of the deep is frozen. (Diski 2005: 133)

The icy womb would appear to take on a three-layered meaning here, including not only the biblical foreboding and the Shackleton calamity, but also the cold womb that Diski sees herself deriving from. Such a relatively heavy-handed symbolic reading, however, seems at odds with the memoir's insistence on the far more elusive and complex metaphor of Schrödinger's box and the dogged assertions of ambivalence.

Diski's childhood trauma is a disaster that cannot be written, but must be written nonetheless. "The disaster," as Maurice Blanchot proposes in The Writing of Disaster, "is related to forgetfulness - forgetfulness without memory, the motionless retreat of what has not been treated - the immemorial, perhaps" (Blanchot 1986: 3). Diski seems to agree. Yet even if disaster, pain, and trauma cannot 
be articulated, we are obliged to, indeed we must and we do, write (about) it, as Blanchot also implies. It is this paradox that Diski enunciates so eloquently in Skating to Antarctica.

The Antarctic remains a paradox: it brings pain by extreme coldness, but also numbness and relief. Being there, in this space of ice, is like being on drugs, we read; it offers a narcotic immobility in which Diski cannot remain, but nevertheless must seek out. Although she explicitly and deliberately tries to stay detached, Diski's stronghold and reserve is ultimately softened during her journey to the cold continent, and she is ready to acknowledge on her return, when her daughter asks her, “'Good to know about your mother at last, eh?'/ 'Mmm. Yes, I think it is”' (Diski 2005: 240).

Ultimately, Diski's dogged insistence on whitening out the dark story of childhood abuse is futile. What I initially called a third possibility in relation to trauma, the suspension of its effects, is seriously troubled at the end of the memoirs when the not-knowing of the fate of Diski's mother finally turns to knowing and the lid of the Schrödinger's box is opened. The mother can no longer be both dead and alive. In fact, as her granddaughter finds out, she died on March $28^{\text {th }} 1988$, and thus had lived more than twenty years after Diski last saw her: "that is, been alive all the time while I had been living my life" (Diski 2005: 232).

The shock for the author is not the realization of her mother's death, but the fact that she had been alive for so long: "it was as if the painting of my past had acquired a shadow, a new presence, separate but lurking darkly around corners in the doorway [...]. And instantly the past looked darker and more cluttered than I had pictured it up till then" (Diski 2005: 232). Subsequently, the image of white forgetfulness turns out to be a rather speckled and polychromatic textual tapestry brimming with heretofore repressed or untold stories. White oblivion, then, is not a functional non-image after all. It cannot suspend the narrative of trauma; it cannot maintain the superposition of states.

At the finish line, the "retrospective possibility that she [the mother] might have made contact” (Diski 2005: 233, my emphasis), and consequently might have continued to traumatize the daughter for another two decades, is deeply disturbing. But the excavated death certificate finally brings some measure of clarity and ultimately purges the desperate need to not-know, eliminates the suspension of trauma, and prompts a curative ending: Diski can finally conclude that to be "really orphaned" is also to be "really safe" (Diski 2005: 233). 


\section{Works cited}

Barthes, Roland (1981) Camera Lucida. Reflections on Photography (New York: Hill and Wang) Bear, Liza and Willoughby Sharp (1970) "Discussion with Heizer, Oppenheim, Smithson" in Robert Smithson The Collected Writings (1996). Edited by Jack Flam (Berkeley: University of California Press), pp. 242-252

Bigell, Werner (2014) "Fear and Fascination: Anti-Landscapes between Material Resistance and Material Transcendence," in David E. Nye and Sarah Elkind (eds.), The Anti-Landscape (New York: Rodopi), pp. 129-148

Blanchot, Maurice (1986) The Writing of Disaster (Lincoln and London: University of Nebraska Press)

Caruth, Cathy (1995) Trauma: Explorations in Memory (Baltimore: John Hopkins University Press)

Diski, Jenny (2005) Skating to Antarctica (London: Virago Press)

Flok, Maria (1998) “Cold Comfort," New York Times. http://www.nytimes.com/books/98/08/ 16/reviews/980816.16flookt.html (accessed 1 October 2017)

Freud, Sigmund (1995) "The Interpretation of Dreams," in The Basic Writings of Sigmund Freud (New York: Random House Basic Library Edition)

Kaplan, E. Ann (2005) Trauma Culture, The Politics of Terror and Loss in Literature and the Media (New York: Rutgers University Press)

McGhee, Robert (2005) The Last Imaginary Place (Oxford: Oxford University Press)

Spufford, Francis (1999) I May Be Some Time. Ice and the English Imagination (New York: St. Martin's Press)

Shelley, Mary (1994) Frankenstein, or the Modern Prometheus (London: Puffin Books) Toner, Paul (1970) "Interview with Robert Smithson" in Robert Smithson The Collected Writings (1996). Edited by Jack Flam (Berkeley: University of California Press), pp. $234-241$

Wilson, Eric G. (2003) A Spiritual History of Ice (New York: Palgrave) 